\section{Making oil out of money?}

A controversial plan to pour billions of dollars of federal funds into commercial development of "synthetic" oil and gas from coal and from oil shale is about to face a crucial test in the US House of Representatives. Colin Norman reports

A SYNTHETIC fuels industry is a keystone of the Ford administration's long range energy research and development (R\&D) strategy. The idea is to forcefeed its growth in the United States to the point where it could begin to supplement dwindling domestic supplies of oil and gas in the 1980s and 1990s. The plan now arousing controversy is embodied in a bill already approved in differing versions by the Senate and by four separate House committees. It would provide up to $\$ 6,000$ million to private industry over the next two years in loan guarantees and other financial assistance for the design and construction of large scale production plants.

According to the bill's supporters, chief of whom is Vice President Nelson Rockefeller, the measure is vitally needed to halt the growing imbalance between supply and demand from domestic oil and gas. Without the production of synthetic fuels, the argument runs, imports will inevitably increase as domestic supplies begin to peter out towards the end of the century. And without federal support now, there will be no synthetic fuels industry in place when it is needed.

To the plan's many opponents, however, the idea is a waste of money, an unnecessary subsidy to the already bloated oil industry, and a gross misapplication of energy R\&D funds.

The latest five-year R\&D plan of the Energy Research and Development Administration (ERDA), published last April, envisages a major role for synthetic fuels in the 1990s, suggesting that they "offer a domestic energy alternative to imported oil and gas". ERDA noted, however, that it will require production of between five and ten million barrels of synthetic fuel a day by 1995 simply to hold imports at their present level, and argued that "for the necessary number of plants to be operating in the mid-1990s, an industrial base on the order of 1 million barrels per day must have to exist by 1985".

ERDA's strategy is thus to press ahead with R\&D on advanced technology for producing oil and gas from coal and shale, but at the same time it is urging industry to move rapidly ahead with the design and construction of demonstration plants using technology already developed. The problem, however, is that such large scale plants are expected to cost about $\$ 1,000$ million apiece, and, since the economics of the enterprise are difficult to predict, industry is having a tough time raising that sort of money. Hence the argument for Congress to provide loan guarantees and other financial incentives to help the industry get into the synthetic fuels business. ERDA officials describe the situation as similar to that faced by the nascent nuclear power industry in the 1950s.

Opponents of the bill have challenged its justification with arguments which go to the root of the Ford administration's energy policy. Led by Representative Richard Ottinger, a Democrat from New York, they support ERDA's programme for developing advanced synthetic fuel technology -ERDA is already funding a number of pilot scale projects jointly with industry-but they argue that it is premature for the Federal Government to pour vast sums of money into commercialisation efforts.

Those arguments received valuable support late last month from the General Accounting Office (GAO), an investigative body controlled by Congress. In unusually blunt language, the report recommended that "Government financial assistance for commercial development of synthetic fuels should not be provided at this time", and suggested that conservation efforts are likely to be much more cost effective.

The GAO study suggested that oil produced from coal or shale could cost between $\$ 18$ and $\$ 30$ per barrel, compared with the current price of about $\$ 12$ for imported crude. It also estimated that synthetic gas would cost at least twice as much to produce as natural gas. Thus, to make the products competitive, the Federal Government would have to provide direct subsidies in the form of price supports or production assistance, the report suggests.

The GAO report was greeted with iubilation by the bill's opponents, coming as it did on the eve of the House debate. But ERDA officials were understandably less enthusiastic. For example, Robert C. Seamans Jr, the Administrator of ERDA, said in a statement that the report "presents strong conclusions and recommendations to the Congress without a sound underlying basis of analysis supporting them". He took issue with most of the report's conclusions, particularly its comparison with future synthetic oil prices with present import prices, and suggested, finally, that its publication would be "damaging to the early implementation of our needed energy supply programs".

Equally disturbed was Representative Olin Teague, Chairman of the House Committee on Science and Technology and the chief architect of the bill. Teague called a committee meeting to discuss the report last week, and suggested that he would not bring the bill to the floor unless he is sure that he has sufficient votes to get it through. Later in the week, he said that he would try to get the bill before the full House as soon as possible, indicating that he feels it will pass.

As for the impact of the bill on the synthetic fuels programme, many officials see it as crucial. William $T$. McCormick, Chief of ERDA's Office of Commercialisation, said last week, for example, that "if this bill doesn't go through, many projects which have been supported by company funds will fold". He added that if the bill fails to pass this year, it will be very difficult to resurrect it next year.

Be that as it may, at least one synthetic fuels programme-the oil shale development effort-is already ailing so much that it may be difficult to revive it simply with a financial injection.

It should be recalled that not too long ago, the vast amounts of oil locked into shale beneath the Rocky Mountains in Colorado, Utah and Wyoming were being touted as the answer to America's energy problems. In January, 1974, the Department of the Interior began to offer small tracts of federal land to the oil industry for testing and development projects. The oil industry paid handsomely for the cpportunity, the first 5,000 acre tract fetching a staggering $\$ 210$ million.

Last month, however, consortia which hold rights to the tracts now leased in Colorado and Utah, withdrew from the programme and asked that the leases be suspended. And late last year, a consortium known as The Oil Shale Company (TOSCO), which was reckoned to be the leader in shale processing technology, announced that it had suspended its own private operations. They all cited the high capital cost of building the plants and a variety of environmental problems as reasons for pulling out.

If Congress passes the Synthetic Fuels Loan Guarantee Bill it may at least help the economics of shale processing, since it would reduce the cost of borrowing funds on the capital market. But, according to an Interior Department official, the prospects for reviving the effort look gloomy. 